\title{
The Ramsay Memorial Laboratory, University College, London.
}

THE new Chemical Engineering Laboratory at University College, London, founded as a memorial to the late Sir William Ramsay, was opened on November I2 by H.R.H. Prince Arthur of Connaught, accompanied by Princess Arthur. There was a large gathering, including Lady Ramsay and representatives of university, professional, and industrial circles.

Sir Robert Robertson from the chair emphasised the need, felt especially during the War, for men trained in the development of chemical operations to the industrial scale. He laid stress on the necessity of thorough preliminary training in chemistry, physics, and mathematics, and also on the need for wholehearted co-operation between the industries themselves and the new department, in providing facilities for students to extend their training to include actual works practice and the investigation of problems on a manufacturing scale. He stated that he noticed recently in America that it is possible for the universities to maintain a small colony of post-graduate students at the factories, working on fundamental plant problems, and that this arrangement seems to work to the utmost advantage of both students and manufacturers. He urged chemical manufacturers in Great Britain to consider the possibility of similar co-operation.

Prince Arthur of Connaught, in declaring the Laboratory open, sketched the history of the Ramsay Memorial Scheme, which has now been carried to completion. The new Laboratories-which are temporary-have been reconstructed and equipped under the guidance of Prof. E. C. Williams. In addition to the funds handed over by the Ramsay Memorial Trustees, the Laboratory has received generous support from many of the great British chemical firms, which, by subscriptions for a period of five years, have ensured a minimum income of I $400 l$. Further support is still needed to enable the Laboratory to rise to its full powers of usefulness to industry.

Mr. W. J. U. Woolcock, president of the Society of Chemical Industry, said that although there has, in the past, been some doubt as to the value of the chemical engineer, he looked forward to this pioneer laboratory, as a result of the course of studies which has been framed, sending out men who will play a great part in British chemical industry. He noticed with great satisfaction that Prof. Williams had laid stress on the planning of the large scale operations with special regard to the underlying chemical and physical phenomena involved, as well as on the actual design and operation of the plant. He foresaw the Laboratory becoming a centre to which chemical manufacturers would send their fundamental problems for solution, and although Great Britain is an old and conservative country, in which tradition dies hard, he appealed to manufacturers to bear in mind the possibility of still further co-operation along the lines indicated by Sir Robert Robertson.

Prof. E. C. Williams, in describing the scope and facilities of the Laboratory, said that the chemical industries require men of the same high scientific imagination and experimental skill as have done such great work in the pure sciences, but they must be trained to apply these gifts to the problems and plant operations of chemical industry. In the Ramsay Laboratory, men would be encouraged to develop processes from the test-tube scale to the industrial scale, and themselves to work out the whole of the data necessary for efficient operation on a commercial scale. Chemical engineering is essentially a quantitative science. Provision is made in the Laboratory for carrying forward investigations to the semiindustrial scale; a special laboratory has been built for this purpose, in which students can erect any plant they desire to their own designs and to meet their own special requirements.

A vote of thanks to His Royal Highness was moved by Sir John Rose Bradford and seconded by $\mathrm{Mr}$. Roscoe Brunner.

After the ceremony, the Laboratory was thrown open for inspection. In addition to chemical and physical laboratories, there are provided a drawing office, mechanics shop, which is available for the use of students, and an industrial laboratory. The guiding principle in the design of the Laboratory has been flexibility. This is particularly apparent in the industrial or semi-large scale laboratory, where structures, services (including steam, gas, water, power, electricity, vacuum, and compressed air), and equipment are designed to give the greatest facility in the erection and operation of any desired experimental plant. The Laboratory is already well equipped with plant planned for quantitative investigation rather than for the illustration of industrial practice, it being felt that the latter can only be satisfactorily obtained at an actual factory.

\section{Innermost Asia: its Geography as a Factor in History.}

SIR AUREL STEIN delivered the first " Asia Lecture " before the Royal Geographical Society on November 3. He chose for his subject an account of his three expeditions to the Tarim Basin in Chinese Turkestan, which he undertook in the years rgoo-I, I906-8, and I913-I5. Sir Aurel has long held a foremost position as an archæologist and explorer. We well remember, many years ago, his interesting investigations into the identity of the site of Mount Aornus, described by the Greek historians, somewhere to the north of Attock, which Alexander the Great besieged on his way to India. Since then he has gone much farther afield, and his chief work has been in Central Asia.

The scene of these explorations lies in the great drainageless basins situated between the Tien-Shan, or "Celestial Mountains," on the north, and the Kun-lun ranges to the south which separate them from Tibet. To the west it abuts on the great mountain masses of the Pamirs, and on the east is bounded by the Nan-Shan forming the watershed towards the Pacific Ocean. This vast area is some I 500 miles long from east to west, and up to 600 miles wide from north to south. But " ground capable of settled life is strictly limited to strings of oases and only a few of them in the extreme east and west offer enough arable soil to support a population of some size. The rest of the area is occupied by huge stretches of desert . . . almost everywhere devoid of water."

This desert differs from the deserts of Arabia and South Africa, where whole tribes move about, sure to find grazing for their flocks, at least at certain seasons of the year. Such is not the case in the deserts of the Tarim Rasin, where "the absence of moisture bans not only human existence, but practically also all animal and plant life," and what life there is, round the scattered oases, is entirely de-

$$
\text { NO. } 2874 \text {, VOL. I I } 4 \text { ] }
$$

